\title{
ВИВЧЕННЯ ДОМІНАНТНИХ СТРАХІВ У ДІТЕЙ З ОНКОЛОГІЧНИМИ ЗАХВОРЮВАННЯМИ НА РІЗНИХ СТАДІЯХ ЛІКУВАННЯ
}

\author{
Скаковська Анастасія \\ Львівський національний університет імені Івана Франка, \\ Західноукраїнський спеціалізований медичний центр, \\ м. Львів, Україна, \\ anastasia.skakovska@ukr.net \\ ORCID https://orcid.org/0000-0001-8103-3258
}

Mema. У статті наведено результати дослідження страхів у дітей молодшого шкільного віку, які мають на онкогематологічні захворювання. Здійснено порівняльний аналіз статевих відмінностей домінантних страхів у дітей 3 онкогематологічними захворюваннями, проведено порівняльний аналіз страхів у трьох вибірках онкологічних пацієнтів із відмінним досвідом хвороби на різних стадіях лікування.

Memoдu. Для виконання завдань дослідження дитячих страхів застосовано методику О. I. Захарова, використано такі методи опрацювання результатів, як порівняльний аналіз (t-test Стьюдента) та однофакторний дисперсійний аналіз (критерій Шеффе).

Результати. За результатами проведеного дослідження онкохворі дівчатка характеризуються наявністю медичних страхів, страхів перед тваринами, казковими героями, страхом власної смерті, смерті батьків, кошмарних снів і страхами, пов’язаними із засинанням. Для досліджуваних хлопчиків 3 онкохворобами більш властиво боятися фізичних ушкоджень та просторових страхів. Установлено відмінні домінантні страхи в дітей з онкологічними захворюваннями з різною тривалістю перебування на лікуванні за шкалами методики виявлення дитячих страхів, також відмінні домінантні страхи в дітей 3 онкологічними захворюваннями та у відносно здорових піi представників із контрольної групи. Виявлено статистично значущі відмінності за шкалами методики дослідження дитячих страхів між респондентами 3 онкологічними захворюваннями, котрі пройшли трансплантацію, та іншими хворими досліджуваної групи, між дітьми 3 онкологічними захворюваннями, які досягли ремісії, із тими, хто не увійшов у ремісію.

Висновки. За даними проведеного дослідження можна визначити, що діти 3 онкогематологічними захворюваннями та відносно здорові представники контрольної групи характеризуються відмінними домінантними страхами. Також можна зробити висновки, що домінантні страхи в дітей 3 онкологічними

ISSN 2308-3743 (Online), ISSN 2227-1376 (Print)

(C) Скаковська А., 2020. Ця стаття відкритого доступу на умовах CC BY-NC 4.0 
захворюваннями значно відрізняються на різних етапах лікування й тісно пов'язані з індивідуальним досвідом хвороби.

Ключові слова: онкогематологічні хвороби, молодший шкільний вік, психологічні особливості.

Skakovska Anastasiia. The Research of Dominant Fears in Children with Cancerous Conditions at Different Stages of Treatment. Purpose. The present article provides the research results of fear in primary school-aged children who suffer from hematologic malignancies. It is performed a benchmarking analysis of gender differences of dominant fears in children with hematological malignancies, fulfilled a comparative study of fears in three samples of cancerous patients. The goal of the research is investigation of prevalent fears in children with cancer diagnosis at different stages of treatment.

Methods. For performing the tasks of studying children's fears, the methodology of O. I. Zakharov was applied with the involvement of such processing results methods as comparative analysis (Student's t-test) and one-way analysis of variance (Scheff's criterion).

Results. Based on the results of the conducted research it is estimated that canceraffected girls are characterized by the presence of medical fears, fears of animals, fears of fabulous (fantastic) characters, fear of own death, fear of parents' death, fear of nightmares, and fears associated with falling asleep. For studied boys with cancer diagnosis it is common to be afraid of physical injures and space fears. It is asserted distinctive dominant fears in cancer pediatric patients with different lengths of hospital stay according to the methodology scale of children's fears identification. It is established distinctive dominant fears in children with malignancies and relatively healthy children from the control group. It is identified statistically significant discrepancy according to the methodology scale of children's fears identification between cancer-affected children under study with the experience of transplantation and other patients from the study group as well as difference between the children under study who achieved remission and the ones who have not achieved disease regression yet.

Conclusions. According to the conducted research, it is estimated that children with hematological malignancies and relatively healthy children from the control group are characterized by distinctive dominant fears. Ultimately, it is possible to elicit that dominant fears in children with hematological malignancies significantly differ depending on the stage of treatment and these fears are tightly connected with individual (personal) experience of the disease.

Key words: hematological malignancies, primary school age, psychological peculiarities.

Скаковская Анастасия. Изучение доминантных страхов у детей с онкологическими заболеваниями на разных стадиях лечения. Цель. В статье приводятся результаты исследования страхов у детей младшего школьного возраста, страдающих онкогематологическими заболеваниями. Проводится 
сравнительный анализ половых различий доминантных страхов у детей с онкогематологическими заболеваниями, сравнительный анализ страхов в трех выборках онкологических пациентов с различным опытом болезни на разных стадиях лечения.

Memodbl. Для выполнения задач исследования детских страхов применялась методика А. И. Захарова, использовались такие методы обработки результатов, как сравнительный анализ (t-test Стьюдента) и однофакторный дисперсионный анализ (критерий Шеффе).

Pезультаты. По результатам проведенного исследования онкобольные девочки характеризуются наличием медицинских страхов, страхов перед животными, сказочными героями, страхом собственной смерти, смерти родителей, кошмарных снов и страхами, связанными с засыпанием. Для исследуемых мальчиков с онкозаболеваниями более характерно бояться физических повреждений и пространственных страхов. Установлены различные доминантные страхи у детей с онкологическими заболеваниями с разной продолжительностью пребывания на лечении по шкалам методики выявления детских страхов, различные доминантные страхи у детей с онкологическими заболеваниями в относительно здоровых детей из контрольной группы. Наблюдались статистически значимые различия за шкалами методики иследования детских страхов между респондентами с онкологическими заболеваниями, прошедшими трансплантацию, и другими больными группы, между исследуемыми детьми с онкологическими заболеваниями, достигшими ремиссии, с теми, кто не вошел в ремиссию.

Bbывды. По данным проведенного исследования можно определить, что дети с онкогематологическими заболеваниями и относительно здоровые из контрольной группы характеризуются отличными доминантными страхами. Также можно сделать выводы, что доминантные страхи у детей с онкологическими заболеваниями значительно отличаются на разных этапах лечения и тесно связанные с индивидуальным опытом болезни.

Ключевые слова: онкогематологические заболевания, младший школьный возраст, психологические особенности.

Вступ. Психосоціальна ситуація хворої дитини, що зумовлена онкологічним захворюванням, i процес лікування негативно впливають на ї̈ загальний розвиток, порушують емоційну рівновагу, викликають занепокоєння та страх. Тривала госпіталізація може призвести до особистісних змін, бути фактором соціальної депривації, фрустрації потреб дитини. Досвід перебування в лікарні здатен активізувати дитячі страхи, спровокувати наявність страхів перед медичними маніпуляціями, страхів смерті, соціальних страхів.

Мета статті - виявити домінантні страхи в дітей, котрі хворіють на онкогематологічні захворювання, здійснити порівняльний аналіз 
статевих відмінностей дитячих страхів, порівняльний аналіз страхів у підгрупах дітей з онкологічними хворобами на різних стадіях лікування.

Психологічні особливості в дітей із гострим лімфобластним лейкозом розкрито в працях І. Кияна (Киян, 2003). Дослідження Д. Ісаєва та I. Шаца стосуються страху смерті в дітей з онкопатологією. Зміст страхів у важкохворих дітей може бути достатньо різним. Це, передусім, страх процедур, хвороби й смерті батьків, бути покинутим батьками, болю (Шац, 2016: 78-79).

Описано 18 видів страхів, із якими зіштовхується онкохвора дитина: 1) страх болю та страждань; 2) страх смерті; 3) страх інвалідизації; 4) страх зміни зовнішнього вигляду; 5) страх розлуки; 6) страх ізоляції й самотності; 7) страх утратити контакт із навколишнім середовищем; 8) страх утратити контакт із близькими; 9) страх перед відкиданням; 10) страх утратити любов; 11) страх перед соціальною стигмою; 12) страх перед психологічною та фізичною залежністю від інших; 13) страх утратити контроль; 14) страх недієздатності; 15) страх обмеження свободи пересування; 16) страх перед новим середовищем; 17) страх перед зниженням якості життя; 18) страх перед невідомим (Góralczyk, 1996).

Дітям з онкологічними захворюваннями притаманне переживання медичних страхів. Дослідження показали, що чим більше онкохворі діти схильні до медичних страхів, тим більше вони характеризуються агресивністю, демонстративністю, егоцентризмом та оптимізмом, низьким рівнем невпевненості в собі й низьким рівнем астенії (Скаковська, 2020).

У випадку хірургічних маніпуляцій дитина зіштовхується зі страхом операції. Пацієнти також мають страх перед наркозом, страхом пробудження в процесі операції, страхом перед болем, а також результатом самої операції.

Також важкохворі діти бояться погіршення результататів досліджень, відчувають страх перед тим, що будуть уведені нові обмеження та заборони (Góralczyk, 2009)

У своїх працях Й. Біннебезель зауважує, що чинником страждань онкохворих дітей здебільшого є страх перед болем, а не конкретно сам біль (Біннебезель, Католик, 2018).

Аналіз малюнків страхів дітей, котрі мають онкогематологічні захворювання та перебувають на лікуванні від одного до трьох тижнів, 
засвідчив, що одним із провідних дитячих страхів є страх перед болем. Результати повторного дослідження, проведеного через п'ять місяців, показали, що більшість малюнків містять тему смерті, яка відображається в таких символах, як війна, кладовище, привиди (Скаковська, 2019).

Екзистенція смерті та страх болю часто пов'язані між собою. В онкохворих дітей виникають специфічні новоутворення уявлень, супроводжуваних емоцією страху та фантазіями про динаміку захворювання й особливості лікування (Католик, Стульківська, 2020).

Онкохвора дитина часто відчуває страх перед емоційним відторгненням батьків і страх розлуки з ними. Припущення, що виникає у свідомості дитини щодо можливості відторгнення батьками, викликає страх самотності, страх розриву емоційних зв'язків (Binnebesel, 2004).

M. Wedekind зауважує, що онкохворі діти схильні до уникаючої поведінки й інших поведінкових девіацій (Wedekind, 2006, цитоване у Бірюкова, 2018).

Шкільна фобія описується в середньому в $10 \%$ у великій вибірці дітей шкільного віку 3 онкологічними захворюваннями. Ця фобія характеризується відмовою вчитися в школі через страх перед неуспішністю в навчанні, соматичними скаргами та страхом перед соціальним відторгненням (Upton \& Eiser, 2006; Куртанова, Бурдукова, Щербакова, Щукіна \& Іванова, 2020).

Дж. Варні й інші дослідники, проводячи свої спостереження за зовнішнім виглядом дітей із нещодавно діагностованим раком, відзначили, що травматичні переживання в них пов'язані зі зміною зовнішнього вигляду, які $є$ результатом хіміотерапевтичного лікування. Такий стан викликає посилення страхів, депресії та тривоги (Varni, Katz, Colegrove, Dolging, 1995).

Також у дітей, хворих на лейкоз, виявлено страх загрози тілесної цілісності, порівняно з іншими дітьми з хронічними захворюваннями (Шац, 2016).

Дитина 3 онкологічним захворюванням стикається зі страхом смерті та танатичною тривогою. Чим старшою $є$ дитина, тим реальніше переживає серйозність захворювання, можливість смерті й висловлює страх із цього приводу. Це пов'язано з численними візитами в лікарню, хворобливими процедурами, емоційним станом батьків, відчуттям реальної загрози.

Д. Ісаєв зазначає, що серйозно хвора дитина може зрозуміти власну близьку смерть, хоча дорослі хотіли б заперечувати це. Діти, як 
i дорослі, використовують різні форми психологічного захисту, щоб відвернути таку страшну можливість. Рідко в цьому віці вони прямо говорять про свою боязнь померти (Ісаєв, 2004: 203).

Д. Шлєповронська вважає, що хворі діти менше бояться смерті, ніж здорові. Авторка також припускає, що це може бути пов'язано 3 активізацією захисних механізмів (Ślepowrońska,1989).

Здійснивши теоретичний аналіз досліджень щодо теми страху, ми бачимо, що недостатньо розкритою залишається проблема вивчення домінантних страхів у дітей 3 онкологічними захворюваннями на різних стадіях лікування, що мають різний досвід хвороби.

Методи та процедура дослідження. Для вивчення дитячих домінантних страхів використано методику діагностики дитячих страхів О. І. Захарова (Захаров, 2000), що здійснювалась у формі опитування. До запропонованого списку страхів віднесено такі групи: медичні страхи (біль, уколи, лікарі, хвороби); страхи, пов'язані з нанесенням фізичної школи (транспорт, несподівані звуки, пожежа, війна, стихії); страхи смерті; страх перед тваринами; страхи казкових героїв; страх темноти та кошмарних снів; соціальні страхи (людей, дітей, покарань, спізнень, самотності); просторові страхи (висоти, глибини, замкнутих просторів) Шкала «Страх смерті» була розмежована нами на окремі шкали: «Страх власної смерті» $\mathrm{i}$ «Страх смерті своїх батьків», що дало змогу конкретизувати, який саме страх смерті є домінантним.

Нами використані такі методи опрацювання результатів. як порівняльний аналіз (t-test Стьюдента) та однофакторний дисперсійний аналіз (критерій Шеффе).

Обговорення результатів. У вивченні психологічних особливостей страхів досліджуваних дітей 3 онкологічними захворюваннями брали участь 77 хлопчиків і 75 дівчаток. Вибірку дослідження становили 152 дитини віком 6-10 років, котрі лікувались із приводу онкогематологічних хвороб у відділенні гематології та інтенсивної хіміотерапії Західноукраїнського спеціалізованого медичного центру (м. Львів), Обласної дитячої клінічної лікарні (м. Рівне), дитячої клініки «Бамбіно Джезу» (м. Рим), Університетьській дитячій клініці (м. Люблін).

Пацієнти які проходили лікування в закордонних клініках, були опитані нами під час перебування в Україні в трактах перерви між хіміотерапією та під час перебування на амбулаторному лікуванні в тракті підтримувальної терапії. Усі діти взяли участь у дослідженні за згодою батьків або опікунів. 
За допомогою порівняльного аналізу, проведеного за критерієм t- Стьюдента, установлено, що досліджувані дівчатка 3 онкологічними хворобами характеризується вищим рівнем схильності до медичних страхів $\left(\mathrm{x}_{\text {хл. }}=2,53, \mathrm{x}_{\text {дівч. }}=2,69\right.$ відповідно при $\left.\mathrm{t}=-0,57 \mathrm{p}=0,56\right)$, страхів перед тваринами, казковими героями $\left(\mathrm{x}_{\mathrm{xл}}=0,89, \mathrm{x}_{\text {дівч. }}=0,97\right.$ при $\mathrm{t}=-0,87$ $\mathrm{p}=0,39)$, страхом власної смерті $\left(\mathrm{x}_{\text {хл. }}=0,51, \mathrm{x}_{\text {дівч. }}=0,56\right.$ при $\mathrm{t}=-0,66$ $\mathrm{p}=0,51)$, страхом смерті батьків $\left(\mathrm{x}_{\text {хл. }}=0,93, \mathrm{x}_{\text {дівч. }}=0,95\right.$ при $\mathrm{t}=-0,30$ $\mathrm{p}=0,76)$, страхом кошмарних снів $\left(\mathrm{x}_{\text {хл. }}=2,16, \mathrm{x}_{\text {дівч. }}=2,28\right.$ при $\mathrm{t}=-0,95$ $\mathrm{p}=0,34)$ та страхами, пов'язаними із засинанням. Досліджувані хлопці 3 онкологічними захворюваннями відзначається більшою схильністю боятися фізичних ушкоджень $\left(\mathrm{x}_{\text {хл. }}=6,78, \mathrm{x}_{\text {дівч. }}=6,77\right.$ при $\left.\mathrm{t}=0,03 \mathrm{p}=0,97\right)$, наявністю соціальних страхів $\left(\mathrm{x}_{\text {хл. }}=5,83, \mathrm{x}_{\text {дівч. }}=5,61\right.$ при $\left.\mathrm{t}=1,05 \mathrm{p}=0,30\right)$, просторових ( $\mathrm{x}_{\text {хл. }}=2,22, \mathrm{x}_{\text {дівч. }}=2,16$ при $\left.\mathrm{t}=0,39 \mathrm{p}=0,70\right)$, порівняно 3 досліджуваними дівчатами (рис. 1).

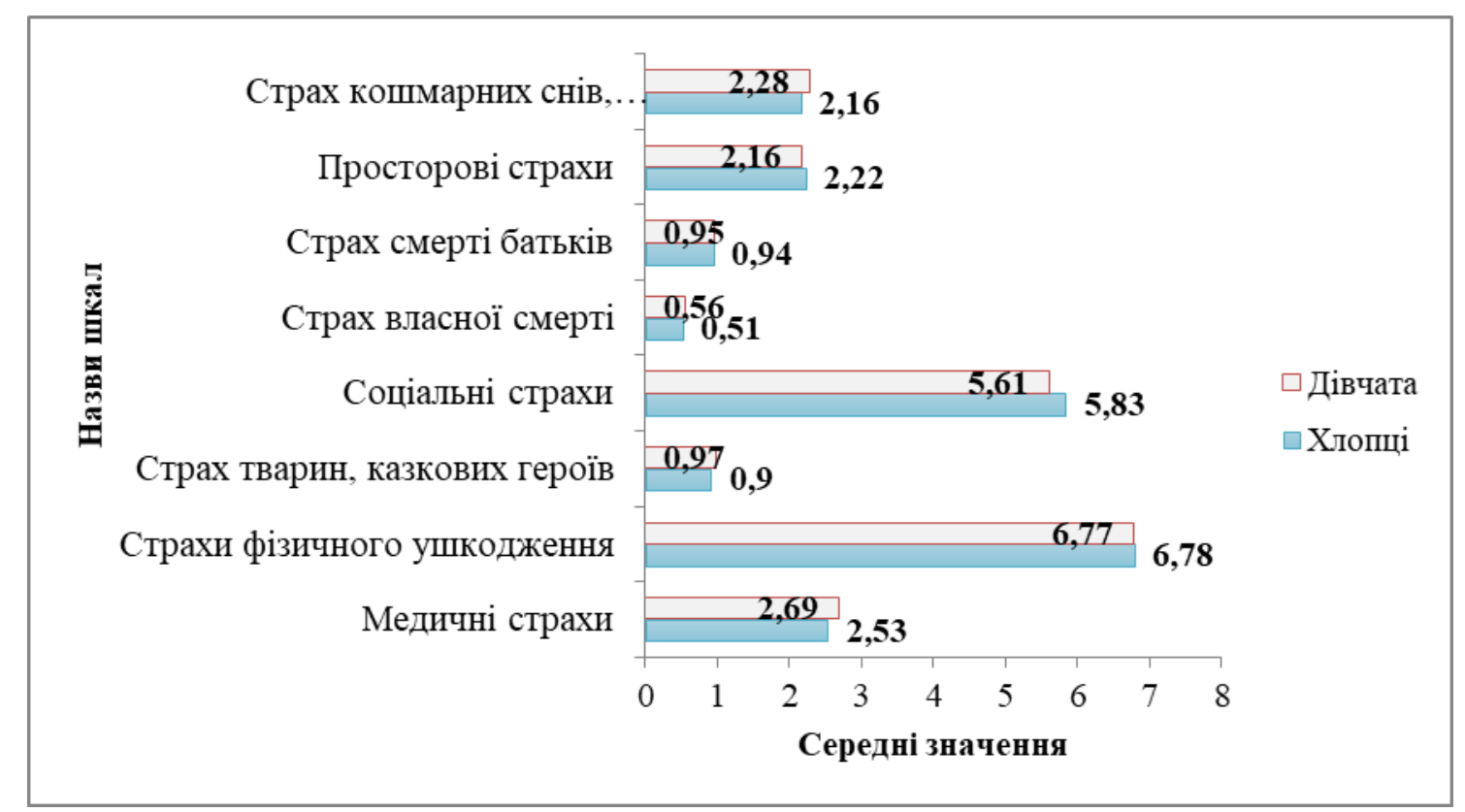

Рис. 1. Результати порівняльного аналізу між досліджуваними дівчатками та хлопчиками з онкологічними захворюваннями за шкалами методики виявлення дитячих страхів A. I. Захарова (t-тест Стьюдента)

У ході дослідження психологічних особливостей страхів у дітей 3 онкологічними захворюваннями також узяли участь 152 відносно здорові дитини, які становили контрольну групу. Серед них - 88 дівчаток та 64 хлопчики, які проходили амбулаторне лікування в Західноукраїнському спеціалізованому дитячому медичному центрі (м. Львів), приватній поліклініці «Мініполіклініка» (м. Львів) із приводу таких 
захворювань, як ангіна, ГРВI, гастрит, отит, бронхіт, захворювання ЖКТ, алергічний дерматит.

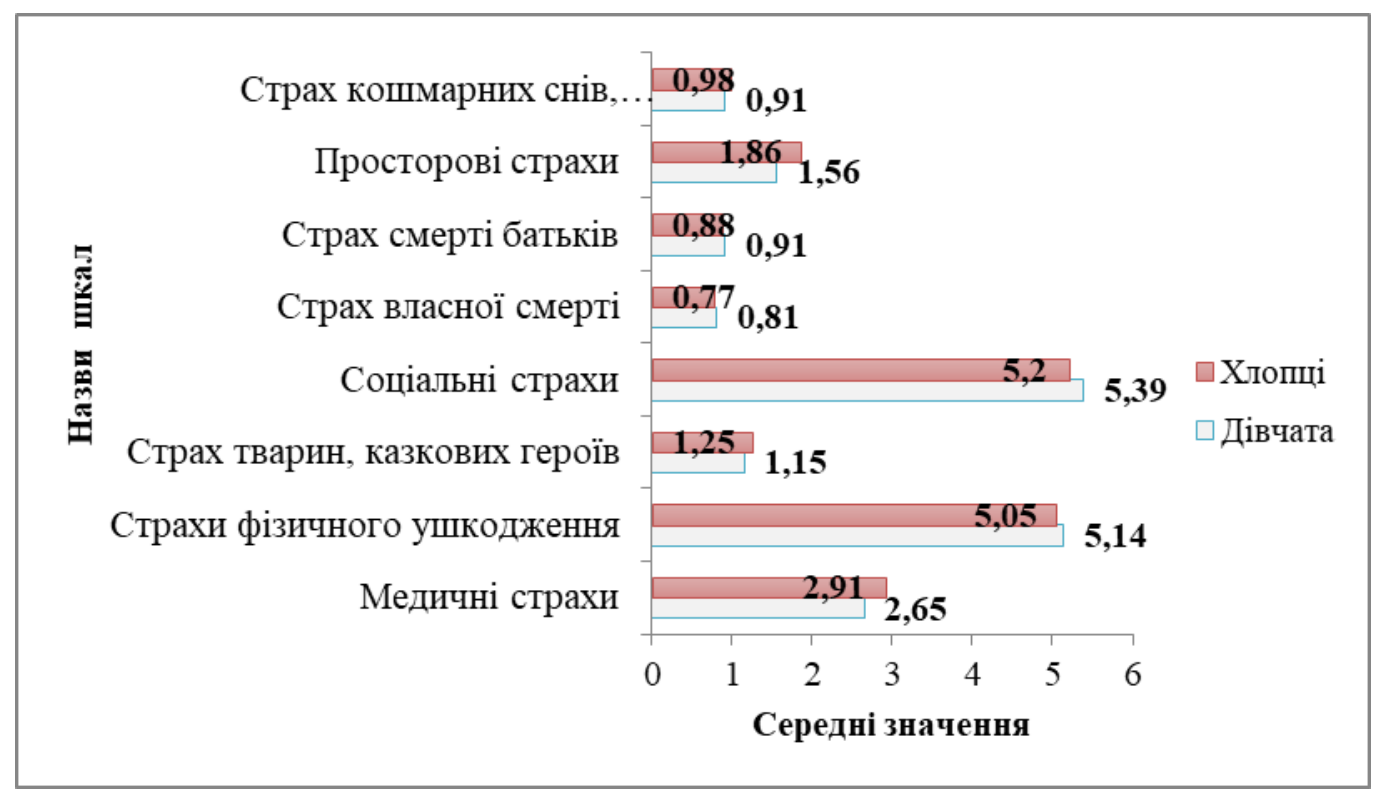

Рис. 2. Результати порівняльного аналізу між досліджуваними дівчатками та хлопчиками з контрольної групи дослідження за шкалами методики виявлення дитячих страхів A. I. Захарова (t-тест Стьюдента)

Виявлено, що вищий рівень схильності переживати медичні страхи $\left(\mathrm{x}_{\text {хл. }}=2,91, \mathrm{x}_{\text {дівч. }}=2,65\right.$ при $\left.\mathrm{t}=-1,26 \mathrm{p}=0,21\right)$, страхи перед тваринами, казковими героями $\left(\mathrm{x}_{\text {хл. }}=1,25, \mathrm{x}_{\text {дівч. }}=1,15\right.$ при $\left.\mathrm{t}=-0,86 \mathrm{p}=0,39\right)$, просторові страхи ( $\mathrm{x}_{\text {хл. }}=1,86, \mathrm{x}_{\text {дівч. }}=1,56$ при $\left.\mathrm{t}=-1,92 \mathrm{p}=0,06\right)$ та страхи кошмарних снів ( $\mathrm{x}_{\text {хл. }}=0,98, \mathrm{x}_{\text {дівч. }}=0,91$ при $\left.\mathrm{t}=-0,50 \mathrm{p}=0,62\right)$ більше притаманні для досліджуваних хлопчиків із контрольної групи, ніж для дівчаток. Водночас останнім властиві високі рівні схильності до страху фізичних ушкоджень $\left(\mathrm{x}_{\text {хл. }}=5,05, \mathrm{x}_{\text {дівч. }}=5,14\right.$ при $\left.\mathrm{t}=0,34 \mathrm{p}=0,73\right)$, соціальні страхи $\left(\mathrm{x}_{\text {хл. }}=5,20, \mathrm{x}_{\text {дівч. }}=5,39\right.$ при $\left.\mathrm{t}=0,89 \mathrm{p}=0,37\right)$, страх власної смерті $\left(\mathrm{x}_{\text {хл. }}=0,77, \mathrm{x}_{\text {дівч. }}=0,81\right.$ при $\left.\mathrm{t}=0,61 \mathrm{p}=0,54\right)$ і страх смерті батьків $\left(\mathrm{x}_{\text {хл. }}=0,88, \mathrm{x}_{\text {дівч. }}=0,91\right.$ при $\left.\mathrm{t}=0,67 \mathrm{p}=0,50\right)$ (рис. 2 ).

Досліджувана група дітей, котрі хворіють на онкологічні захворювання, поділена на три підгрупи за тривалістю перебування на лікуванні: 1-ша складалася 354 дітей, які первинно перебувають на лікуванні, 2-га - із 87 осіб, котрі перебувають протягом довгого часу в лікарні, та 3-тя - 311 дітей, які перебувають на амбулаторному лікуванні в тракті підтримувальної хіміотерапії (рис. 3).

У ході однофакторного дисперсійного порівняльного аналізу встановлено, що досліджувані діти, котрі первинно перебувають на 
лікуванні, характеризується найвищим рівнем схильності боятися медичних страхів $\left(\mathrm{M}_{\text {первинно }}=4,59 ; \mathrm{M}_{\text {тривало }}=1,55 ; \mathrm{M}_{\text {амбулаторно }}=1,27\right)$, а також страхів тварин, казкових героїв $\left(\mathrm{M}_{\text {первинно }}=1,17 ; \mathrm{M}_{\text {тривало }}=0,80\right.$; $\left.\mathrm{M}_{\text {амбулаторно }}=0,82\right)$, страху власної смерті $\left(\mathrm{M}_{\text {первинно }}=0,85 ; \mathrm{M}_{\text {тривало }}=0,37\right.$; $\left.\mathrm{M}_{\text {амбулаторно }}=0,27\right)$, просторові страхи $\quad\left(\mathrm{M}_{\text {первинно }}=2,56 ; \quad \mathrm{M}_{\text {тривало }}=1,98\right.$; $\left.\mathrm{M}_{\text {амбулаторно }}=2,09\right) \quad \mathrm{i}$ страхи кошмарних снів $\left(\mathrm{M}_{\text {первинно }}=2,61\right.$; $\left.\mathrm{M}_{\text {тривало }}=2,05 ; \mathrm{M}_{\text {амбулаторно }}=1,64\right)$. Проте їм найменше притаманні страхи фізичних ушкоджень, соціальні страхи, порівняно $з$ представниками інших підгруп.

Опитані, які довго перебувають на лікуванні, відзначилися найвищими рівнями схильності боятися страху смерті батьків $\left(\mathrm{M}_{\text {первинно }}=0,93 ; \mathrm{M}_{\text {тривало }}=0,97 ; \mathrm{M}_{\text {амбулаторно }}=0,82\right)$ та найнижчими рівнями схильності боятися тварин, казкових героїв і просторових страхів.

Опитані 3 амбулаторного лікування характеризується вищими рівнями, порівняно з іншими опитаними, схильності боятися фізичних ушкоджень $\quad\left(\mathrm{M}_{\text {первинно }}=6,30 ; \quad \mathrm{M}_{\text {тривало }}=7,02 ; \quad \mathrm{M}_{\text {амбулаторно }}=7,18\right) \quad$ та наявністю соціальних страхів $\left(\mathrm{M}_{\text {первинно }}=5,02 ; \quad \mathrm{M}_{\text {тривало }}=6,03\right.$; $\left.\mathrm{M}_{\text {амбулаторно }}=6,73\right)$. Також для дітей $з$ останньої підгрупи притаманні найнижчий рівень схильності до медичних страхів, страху власної смерті, страхами смерті батьків і кошмарних снів.

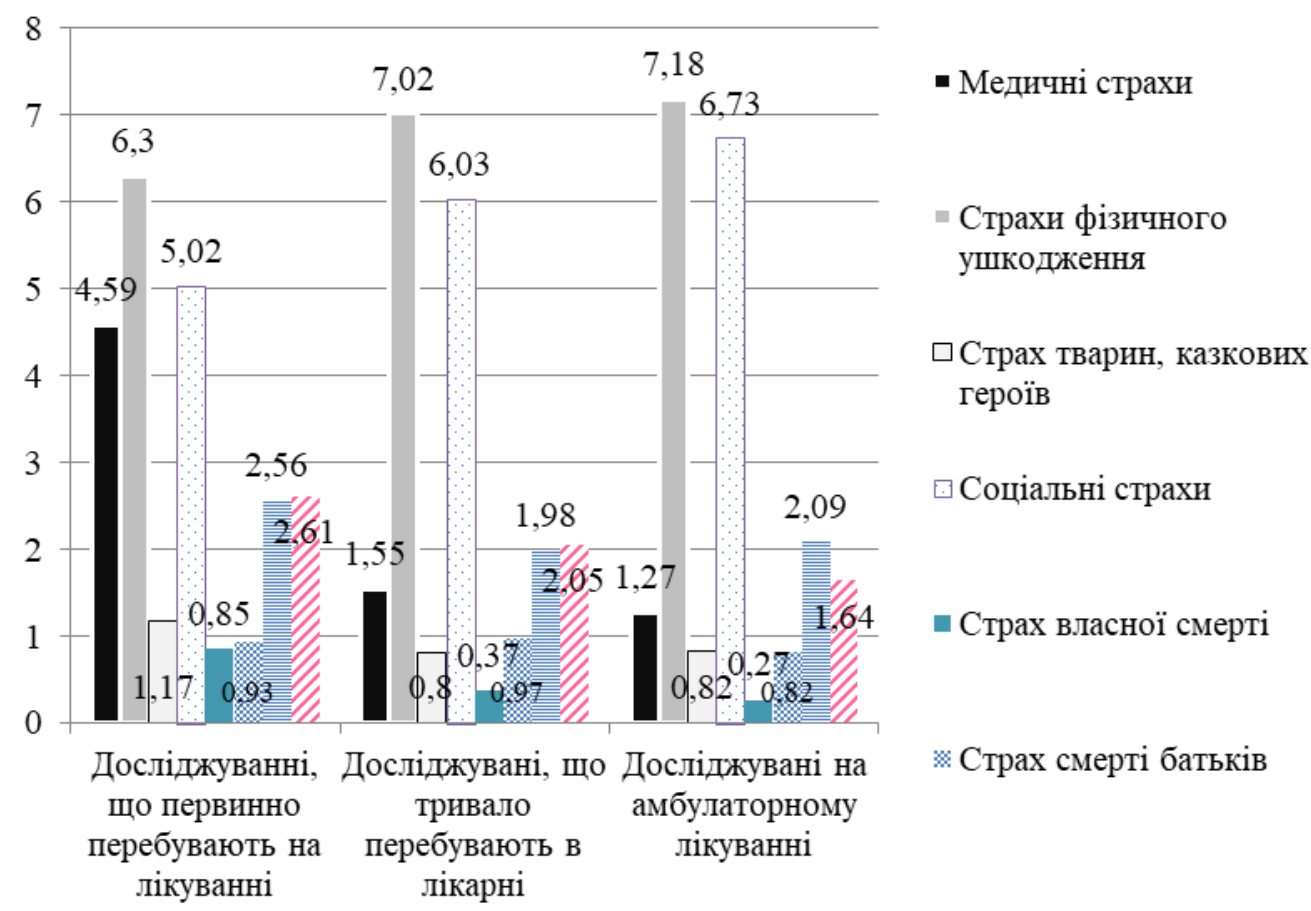

Рис. 3. Результати однофакторного дисперсійного аналізу між досліджуваними дітьми з онкологічними захворюваннями з різною тривалістю перебування на лікуванні за шкалами методики виявлення дитячих страхів А. I. Захарова 
У ході порівняльного аналізу дітей із досліджуваної групи поділено на дві підгрупи - 141 дитина, яка не досягла ремісії, та 11 тих, котрі досягли ремісії. За допомогою порівняльного аналізу цих підгруп установлено статистично значущі відмінності за шкалами методики А. І. Захарова (рис. 4). А саме опитані, які не $є$ в ремісії, характеризуються вищими рівнями медичної страхів $\left(\mathrm{x}_{\text {відс_ремісія }}=2,72\right.$, $\mathrm{x}_{\text {ремісія }}=1,27$ при $\left.\mathrm{t}=2,73 \mathrm{p}=0,007\right)$, страхів кошмарних снів, темноти $\left(\mathrm{x}_{\text {відс_ремісія }}=2,26, \mathrm{x}_{\text {ремісія }}=1,64\right.$ при $\left.\mathrm{t}=2,53 \mathrm{p}=0,01\right)$, порівняно з дітьми, які досягли ремісії. Для останніх характерні вищі рівні схильності переживати соціальні страхи $\left(\mathrm{x}_{\text {відс_ремісія }}=5,64, \mathrm{x}_{\text {ремісія }}=6,73\right.$ при $\mathrm{t}=-2,75$ $\mathrm{p}=0,007)$.

Також виявлено відмінності, порівняння дітей за наявністю чи відсутністю ремісії в схильності боятися фізичних ушкоджень ( $\mathrm{x}_{\text {відс_ремісія }}=6,74, \mathrm{x}_{\text {ремісія }}=7,18$ при $\left.\mathrm{t}=-1,29 \mathrm{p}=0,20\right)$, тварин казкових героїв ( $\mathrm{x}_{\text {відс_ремісія }}=0,94, \mathrm{x}_{\text {ремісія }}=0,82$ при $\left.\mathrm{t}=0,73 \mathrm{p}=0,47\right)$, страху власної смерті $\left(\mathrm{x}_{\text {відс_емісія }}=0,55, \mathrm{x}_{\text {ремісія }}=0,27\right.$ при $\left.\mathrm{t}=1,8 \mathrm{p}=0,07\right)$, страху смерті батьків $\left(\mathrm{x}_{\text {відс_ремісія }}=0,95, \mathrm{x}_{\text {ремісія }}=0,82\right.$ при $\left.\mathrm{t}=1,80 \mathrm{p}=0,01\right)$, просторових страхів $\left(\mathrm{x}_{\text {відс_ремісія }}=2,20, \mathrm{x}_{\text {ремісія }}=2,09\right.$ при $\left.\mathrm{t}=0,36 \mathrm{p}=0,72\right)$. Опитані, котрі пережили ремісію, схильні більше боятися страху фізичних ушкоджень. Діти, які не досягли ремісії, здатні менше боятися страху фізичних ушкоджень, проте в них домінують страхи тварин казкових героїв, страх власної смерті, страх смерті батьків, просторові страхи.

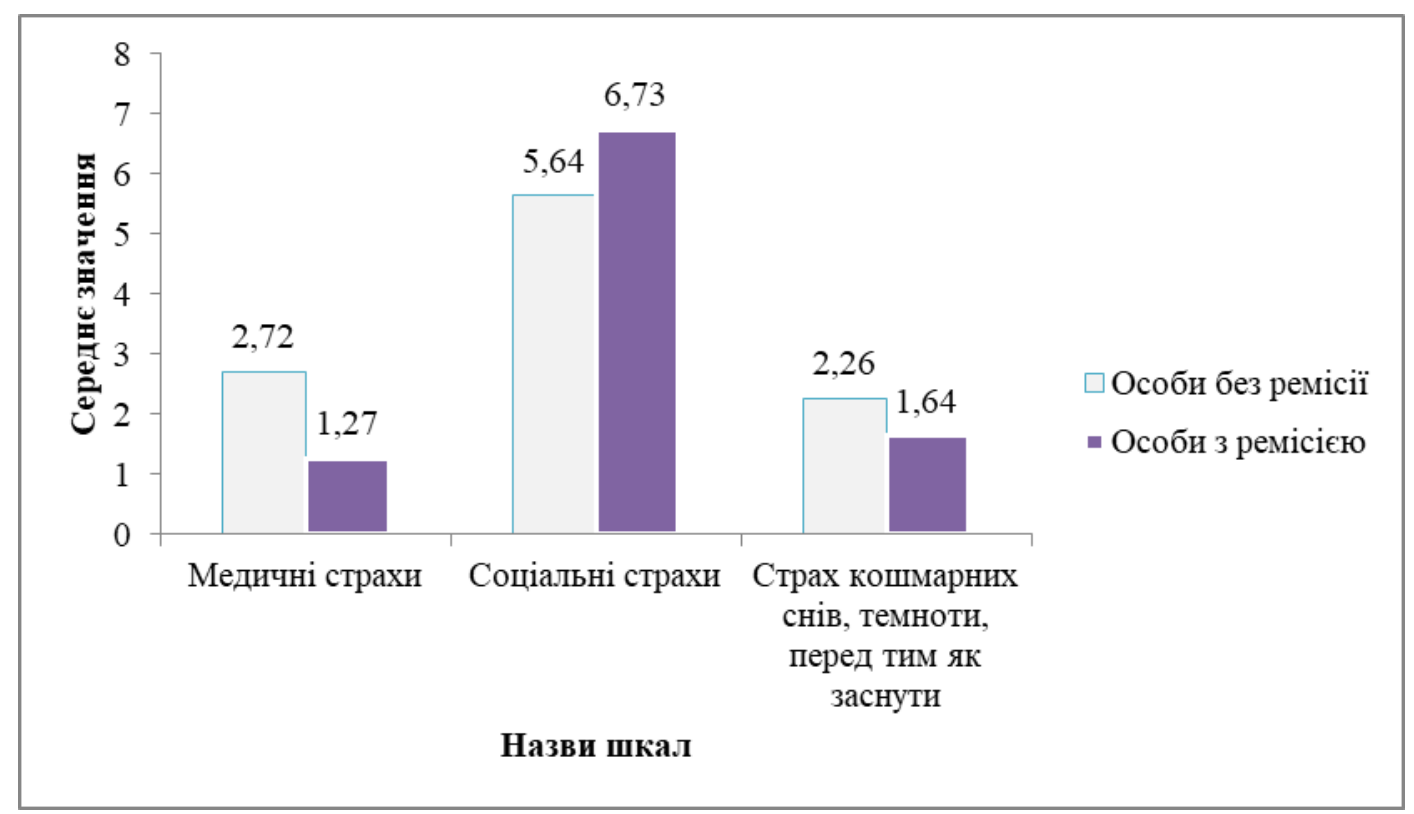

Рис. 4. Статистично значущі відмінності між досліджуваними дітьми з онкологічними захворюваннями, які переживають ремісію, із тими, хто не переживає ï, за шкалами методики виявлення дитячих страхів А. I. Захарова ( $t$-тест Стьюдента) 
Досліджувану групу поділена на підгрупи за наявністю досвіду реанімації. Розподіл здійснено на дві підгрупи: у 1-шу ввійшло 114 осіб, котрі не мають досвіду реанімації, у 2-гу - 38, із досвідом реанімації. За допомогою порівняльного аналізу встановлено, що діти 3 досвідом реанімації характеризується вищими рівнями страхів фізичних ушкоджень $\left(\mathrm{x}_{\text {відс_реанімація }}=6,65, \mathrm{x}_{\text {досвід_реанімаціі }}=7,16\right.$ при $\mathrm{t}=-2,54$ $\mathrm{p}=0,01$ ), порівняно $з$ тими, які не мають відповідного досвіду (рис. 5). Опитані діти без досвіду реанімації відзначаються високим рівнем схильності боятися медичних страхів $\quad\left(\mathrm{x}_{\text {відс реанімація }}=2,98\right.$, $\mathrm{x}_{\text {досвід_реанімаціi }}=1,5$ при $\left.\mathrm{t}=4,92 \mathrm{p}=0,00\right)$ та страху власної смерті $\left(\mathrm{x}_{\text {відс_реанімація }}=0,70, \mathrm{x}_{\text {досвід_реанімаціі }}=0,03\right.$ при $\left.\mathrm{t}=8,86 \mathrm{p}=0,000\right)$.

Також виявилося, що діти, які не мають досвіду реанімації, більше бояться тварин казкових героїв $\left(\mathrm{x}_{\text {відс_реанімація }}=0,96, \mathrm{x}_{\text {досвід_реанімації }}=0,84\right.$ при $\mathrm{t}=1,20 \mathrm{p}=0,23), \quad$ просторових страхів $\quad\left(\mathrm{x}_{\text {відс_реанімація }}=2,26\right.$, $\mathrm{x}_{\text {досвід_реанімаціі }}=1,97$ при $\left.\mathrm{t}=1,62 \mathrm{p}=0,11\right)$, ніж опитані 3 наявним відповідним досвідом, у той час, як останні характеризуються вищими рівнями схильності переживати соціальні страхи $\left(\mathrm{x}_{\text {відс_реанімація }}=5,66\right.$, $\mathrm{x}_{\text {досвід_реанімаціі }}=5,92$ при $\left.\mathrm{t}=-1,20 \mathrm{p}=0,27\right)$, страхи смерті батьків $\left(\mathrm{x}_{\text {відс_реанімація }}=0,93, \mathrm{x}_{\text {досвід_реанімаціi }}=0,97\right.$ при $\left.\mathrm{t}=-0,99 \mathrm{p}=0,32\right)$ та страхи кошмарних снів $\quad\left(\mathrm{x}_{\text {відс_реанімація }}=2,21, \mathrm{x}_{\text {досвід_реанімаціі }}=2,24\right.$ при $\mathrm{t}=-0,17$ $\mathrm{p}=0,86)$.

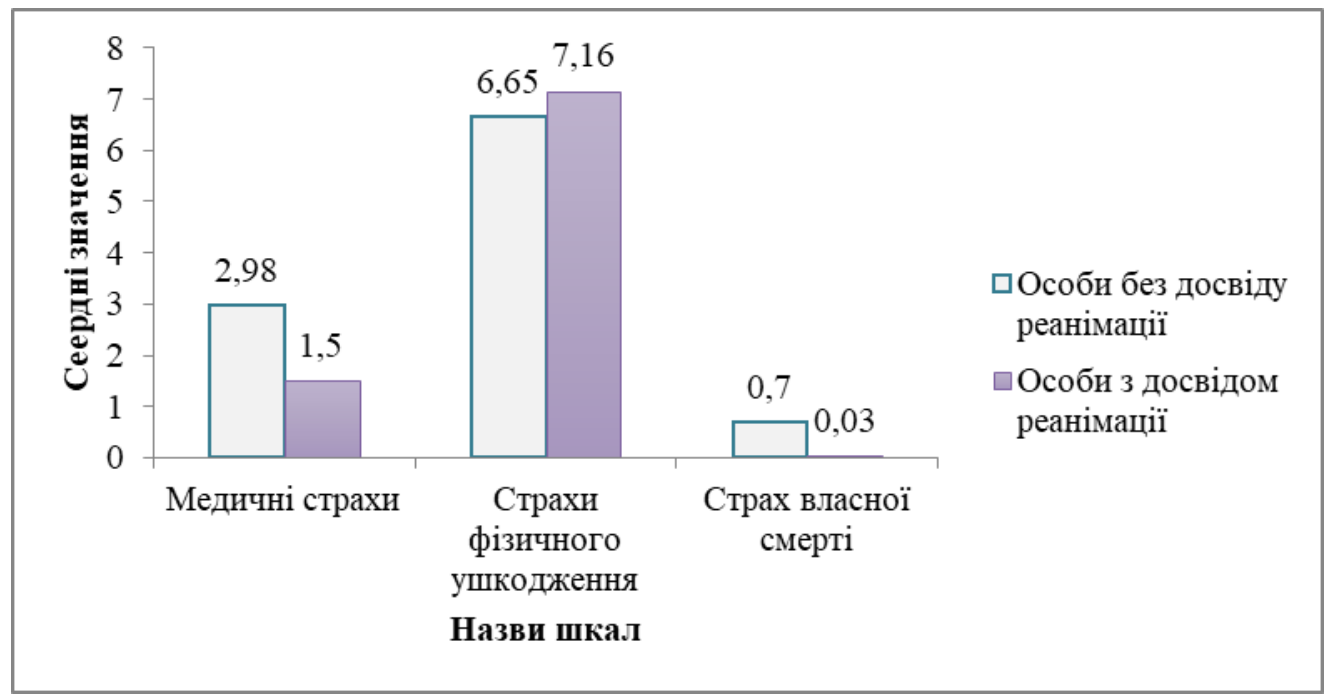

Рис. 5. Статистично значущі відмінності між досліджуваними дітьми з онкологічними захворюваннями з різним досвідом реанімації за шкалами методики виявлення дитячих страхів А. I. Захарова, (t-тест Стьюдента)

Дітей, які взяли участь у дослідженні, розподілено на 26 дітей, котрі мають рецидив онкогематологічного захворювання, і на 126 тих, 
які не мали рецидиву. Завдяки порівнянню цих підгруп виявлено статистично значущі відмінності за схильністю до медичних страхів $\left(\mathrm{x}_{\text {рецедив }}=1,46, \mathrm{x}_{\text {відс. рецедив }}=2,85\right.$ при $\left.\mathrm{t}=-3,9 \mathrm{p}=0,00\right)$, страхом власної смерті $\left(\mathrm{x}_{\text {рецедив }}=0,12, \mathrm{x}_{\text {відс. } е \text { рецедив }}=0,62\right.$ при $\left.\mathrm{t}=-5,03 \mathrm{p}=0,00\right)$ та просторовими страхами $\left(\mathrm{x}_{\text {рецедив }}=1,69, \mathrm{x}_{\text {відс. рецедив }}=7,16\right.$ при $\left.\mathrm{t}=-2,98 \mathrm{p}=0,00\right)$ (рис. 6).

Установлено, що діти, які мають рецидив онкогематологічного захворювання, характеризуються меншим рівнем схильності боятися медичних страхів, нижчим рівнем страху власної смерті та низьким рівнем просторових страхів, у той час як опитані, які не мали рецидиву онкологічного захворювання, характеризується вищим рівнем страху перед тваринами $\left(\mathrm{x}_{\text {рецедив }}=0,81, \mathrm{x}_{\text {відс. рецедив }}=0,96\right.$ при $\mathrm{t}=-1,30$ $\mathrm{p}=0,20)$, казковими героями, вищим рівнем страху власної смерті, страху смерті батьків $\left(\mathrm{x}_{\text {рецедив }}=1, \mathrm{x}_{\text {відс._рецедив }}=0,93\right.$ при $\left.\mathrm{t}=1,40 \mathrm{p}=0,16\right)$, просторові страхи та страху кошмарних снів $\quad\left(\mathrm{x}_{\text {рецедив }}=2,12\right.$, $\mathrm{x}_{\text {відс. рецедив }}=2,24$ при $\left.\mathrm{t}=-0,70 \mathrm{p}=0,48\right)$. Наявність рецидиву в дітей 3 онкологічними захворюваннями також відзначається вищими рівнями схильності до соціальних страхів $\left(\mathrm{x}_{\text {рецедив }}=5,96, \mathrm{x}_{\text {відс. рецедив }}=5,67\right.$ при $\mathrm{t}=1,04 \mathrm{p}=0,3)$ та страхів фізичних ушкоджень $\quad\left(\mathrm{x}_{\text {рецедив }}=7,08\right.$, $\mathrm{x}_{\text {відс. рецедив }}=6,71$ при $\mathrm{t}=1,06 \mathrm{p}=0,12$ ), порівняно з особами, які не мали досвіду рецидиву захворювання.

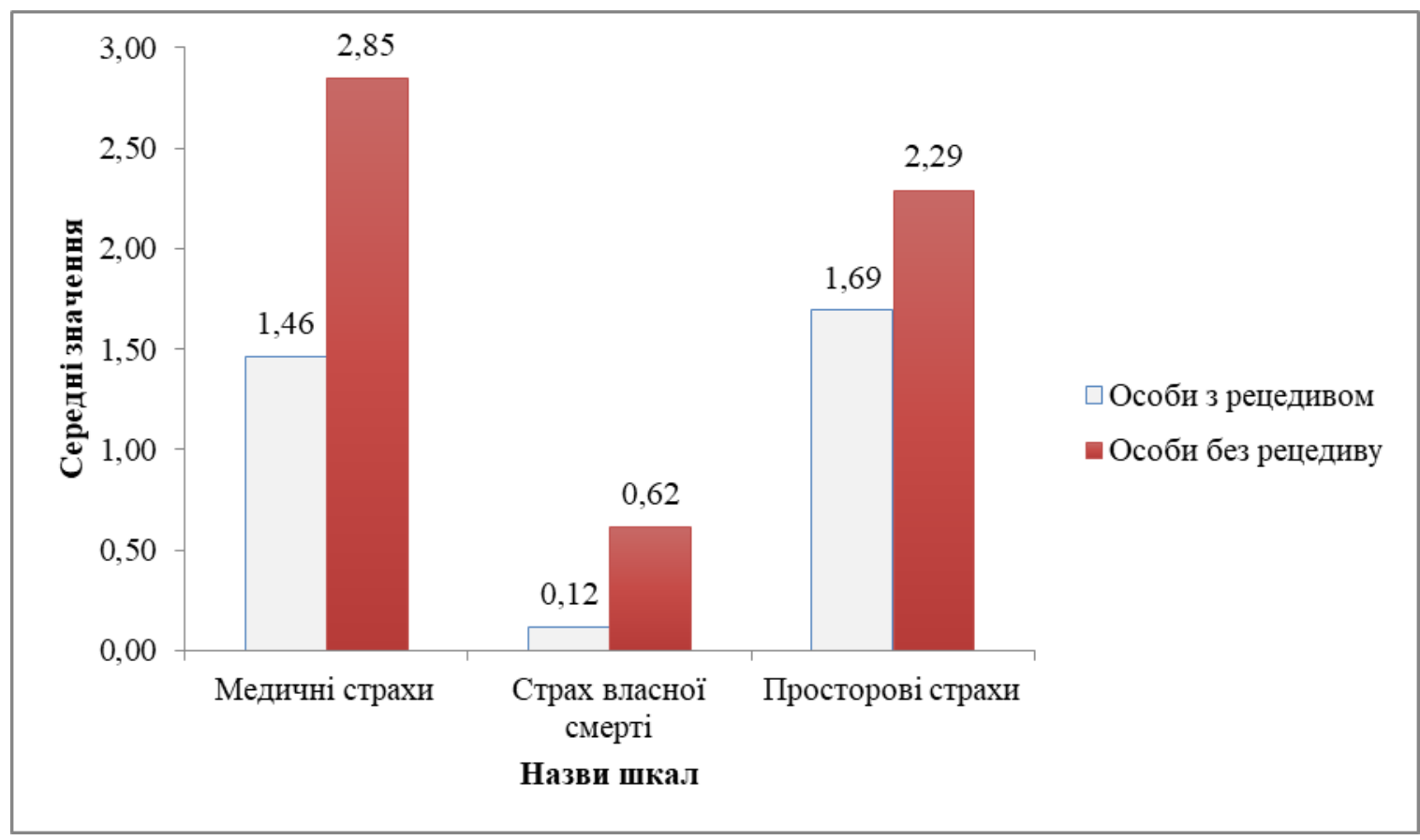

Рис. 6. Статистично значущі відмінності між досліджуваними дітьми з онкологічними захворюваннями, що переживають рецидив із тими, хто не переживає його, за шкалами методики виявлення дитячих страхів A. I. Захарова (t-тест Стьюдента) 
У дослідженні взяли участь 152 дитини, які мають онкогематологічні захворювання, вісім із них перебували на термінальній стадії захворювання зі здійсненням паліативного супроводу. Порівняння цих досліджуваних показало статистично значущі відмінності в схильності боятися медичних страхів $\left(\mathrm{x}_{\text {непаліативні }}=2,69, \mathrm{x}_{\text {паліативні }}=1,25\right.$ при $\mathrm{t}=2,32$ $\mathrm{p}=0,02)$, страхів власної смерті $\left(\mathrm{x}_{\text {непаліативні }}=0,56, \mathrm{x}_{\text {паліативні }}=0,00\right.$ при $\mathrm{t}=3,19 \mathrm{p}=0,002$ ) (рис. 7). Виявлено, що діти, котрі перебувають на термінальній стадії захворювання, характеризуються нижчим рівнем схильності боятися власної смерті й низьким рівнем схильності боятися медичних страхів, порівняно з тими, які не перебувають на термінальній стадії онкозахворювання. Також простежено, що діти на термінальній стадії захворювання більше схильні боятися страху фізичних ушкоджень $\left(\mathrm{x}_{\text {непаліативні }}=6,76, \mathrm{x}_{\text {паліативні }}=7\right.$ при $\left.\mathrm{t}=-0,60 \mathrm{p}=0,55\right)$ та страху кошмарних снів $\left(\mathrm{x}_{\text {непаліативні }}=2,22, \mathrm{x}_{\text {паліативні }}=2,25\right.$ при $\mathrm{t}=-0,12$ $\mathrm{p}=0,91)$. Не паліативні пацієнти більше схильні боятися страху тварин казкових героїв $\left(\mathrm{x}_{\text {непаліативні }}=0,94, \mathrm{x}_{\text {паліативні }}=0,88\right.$ при $\left.\mathrm{t}=0,31 \mathrm{p}=0,75\right)$, соціальних страхів $\left(\mathrm{x}_{\text {непаліативні }}=5,76, \mathrm{x}_{\text {паліативні }}=5\right.$ при $\left.\mathrm{t}=1,65 \mathrm{p}=0,10\right)$, страху смерті батьків $\quad\left(\mathrm{x}_{\text {непаліативні }}=0,94, \mathrm{x}_{\text {паліативні }}=0,87\right.$ при $\mathrm{t}=0,81$ $\mathrm{p}=0,42)$, просторових страхів $\left(\mathrm{x}_{\text {непаліативні }}=2,22, \mathrm{x}_{\text {паліативні }}=1,75\right.$ при $\mathrm{t}=1,34$ $\mathrm{p}=0,18)$.

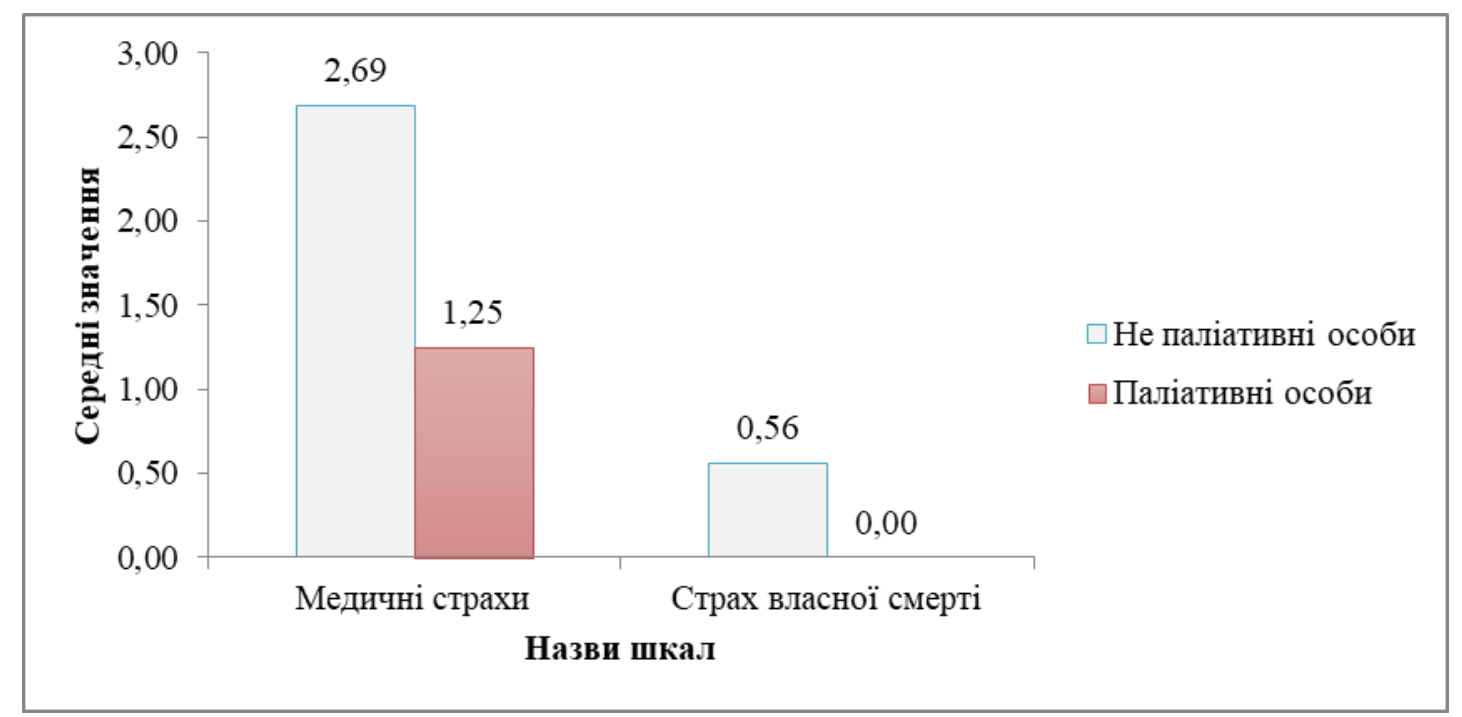

Рис. 7. Статистично значущі відмінності між досліджуваними дітьми з онкологічними захворюваннями із різними рівнями паліативності за шкалами методики виявлення дитячих страхів A. I. Захарова (t-тест Стьюдента)

Пацієнтів поділено відповідно до відповідей анкетування батьків за тим, чи готується дитина до трансплантації кісткового мозку (ТКМ). 
За допомогою розподілу виявлено 139 дітей, котрі не готуються до ТКМ, та 13 тих, які готуються до неї (рис. 8). Опитані, котрі готуються до ТКМ, виявили нижчий рівень схильності боятися медичних страхів ( $\mathrm{x}_{\text {iншi }}=2,74, \mathrm{x}_{\text {до_транспл. }}=1,23$ при $\left.\mathrm{t}=3,1 \mathrm{p}=0,002\right)$ та страху власної смерті $\left(\mathrm{x}_{\text {iнші }}=0,58, \mathrm{x}_{\text {до_транспл. }}=0,00\right.$ при $\left.\mathrm{t}=4,23 \mathrm{p}=0,00\right)$, порівняно 3 дітьми, котрі не готуються до трансплантації. Також виявлено, що діти, які готуються до трансплантації, бояться страху фізичних ушкоджень $\left(\mathrm{x}_{\text {інші }}=6,76 \mathrm{x}_{\text {до_транспл. }}=7\right.$ при $\left.\mathrm{t}=-0,77 \mathrm{p}=0,44\right)$, страху смерті батьків $\left(\mathrm{x}_{\text {iнші }}=0,94, \mathrm{x}_{\text {до_транспл. }}=1\right.$ при $\left.\mathrm{t}=-0,94 \mathrm{p}=0,35\right)$, страху кошмарних снів темноти $\left(\mathrm{x}_{\text {інші }}=2,22, \mathrm{x}_{\text {до_транспл. }}=2,23\right.$ при $\mathrm{t}=-0,06$ $\mathrm{p}=0,95)$ більшою мірою, ніж інші діти з онкологічним захворюванням. Опитані, які не готуються до трансплантації, відзначаються вищим рівнем схильності боятися тварин казкових героїв $\left(\mathrm{x}_{\text {ннші }}=0,94\right.$, $\mathrm{x}_{\text {до_транспл. }}=0,92$ при $\left.\mathrm{t}=0,08 \mathrm{p}=0,94\right)$, соціальних страхів $\quad\left(\mathrm{x}_{\text {ннші }}=5,73\right.$, $\mathrm{x}_{\text {до_транспл. }}=5,69$ при $\left.\mathrm{t}=0,09 \mathrm{p}=0,93\right)$ та просторових $\quad\left(\mathrm{x}_{\text {інші }}=2,24\right.$, $\mathrm{x}_{\text {до_транспл. }}=1,69$ при $\left.\mathrm{t}=1,97 \mathrm{p}=0,05\right)$.

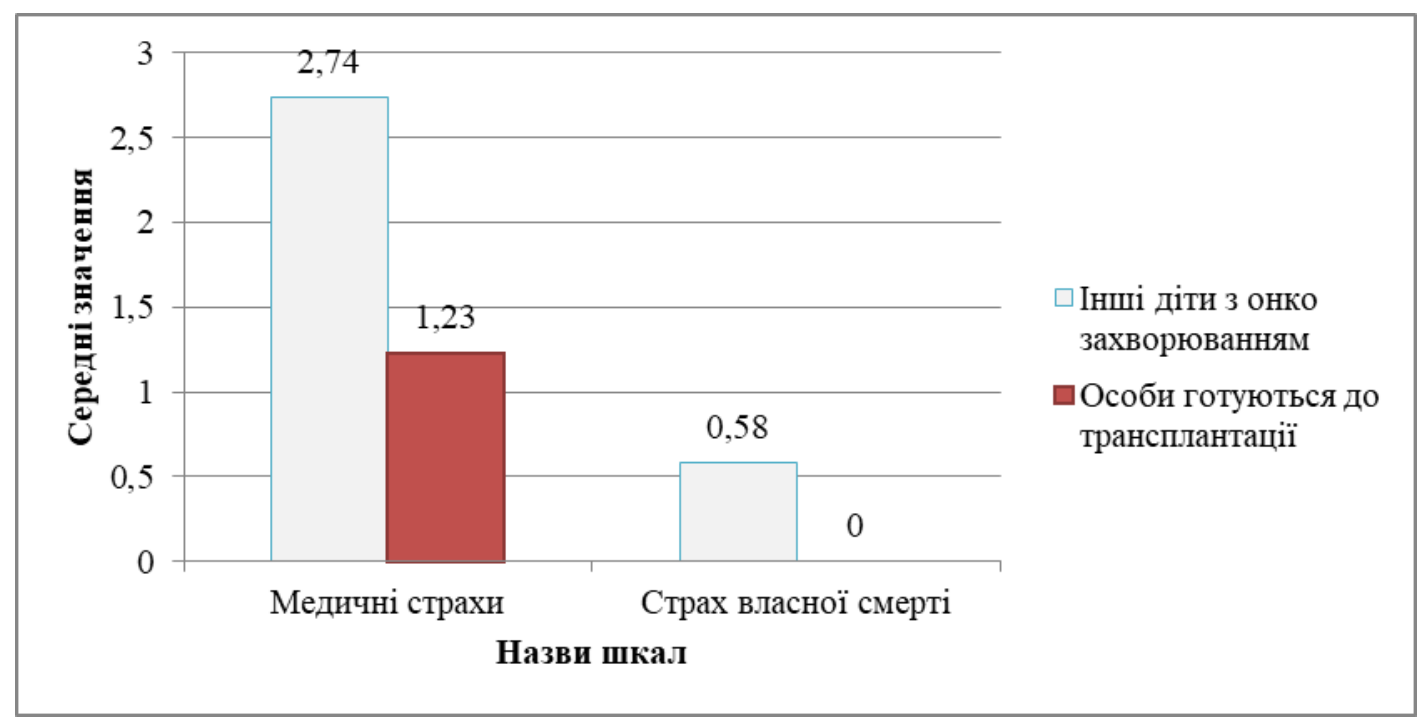

Рис. 8. Статистично значущі відмінності між досліджуваними дітьми з онкологічними захворюваннями, які готуються до трансплантації, та іншими хворими досліджуваної групи за шкалами методики виявлення дитячих страхів O. I. Захарова (t-тест Стьюдента)

Досліджувану групу становили п’ять дітей, які пройшли ТКМ, та інші представники досліджуваної групи з онкологічними захворюваннями. За допомогою порівняльного аналізу встановлено, що діти після трансплантації менше схильні боятися медичних страхів ( $\mathrm{x}_{\text {після_транспл. }}=1, \mathrm{x}_{\text {iншi }}=2,67$ при $\mathrm{t}=-2,14 \mathrm{p}=0,03$ ), страху власної смерті 
( $\mathrm{x}_{\text {після транспл. }}=0, \mathrm{x}_{\text {iнші }}=0,55$ при $\left.\mathrm{t}=-2,46 \mathrm{p}=0,01\right)$ i просторових страхів $\left(\mathrm{x}_{\text {після_транспл. }}=1,2, \mathrm{x}_{\text {інші }}=2,22\right.$ при $\left.\mathrm{t}=-2,38 \mathrm{p}=0,02\right)$, ніж діти, у яких відсутня трансплантація чи які готуються до неї (рис. 9). Останні характеризуються вищим рівнем страху фізичних ушкоджень $\left(\mathrm{x}_{\text {після_транспл. }}=6,6, \mathrm{x}_{\text {iнші }}=6,78\right.$ при $\left.\mathrm{t}=-0,37 \mathrm{p}=0,71\right)$, страху тварин казкових героїв ( $\mathrm{x}_{\text {після_транспл. }}=0,6, \mathrm{x}_{\text {iнші }}=0,95$ при $\left.\mathrm{t}=-1,39 \mathrm{p}=1,66\right)$, страху смерті батьків $\left(\mathrm{x}_{\text {після_транспл. }}=1, \mathrm{x}_{\text {iншi }}=0,94\right.$ при $\left.\mathrm{t}=0,57 \mathrm{p}=0,57\right)$, страхами кошмарних снів $\mathrm{i}$ темноти ( $\mathrm{x}_{\text {після транспл. }}=1,8, \mathrm{x}_{\mathrm{iншi}}=2,23$ при $\mathrm{t}=-1,18$ $\mathrm{p}=0,24)$ та соціальними страхами $\left(\mathrm{x}_{\text {після_транспл. }}=6, \mathrm{x}_{\text {iнші }}=5,71\right.$ при $\mathrm{t}=0,49$ $\mathrm{p}=0,63)$.

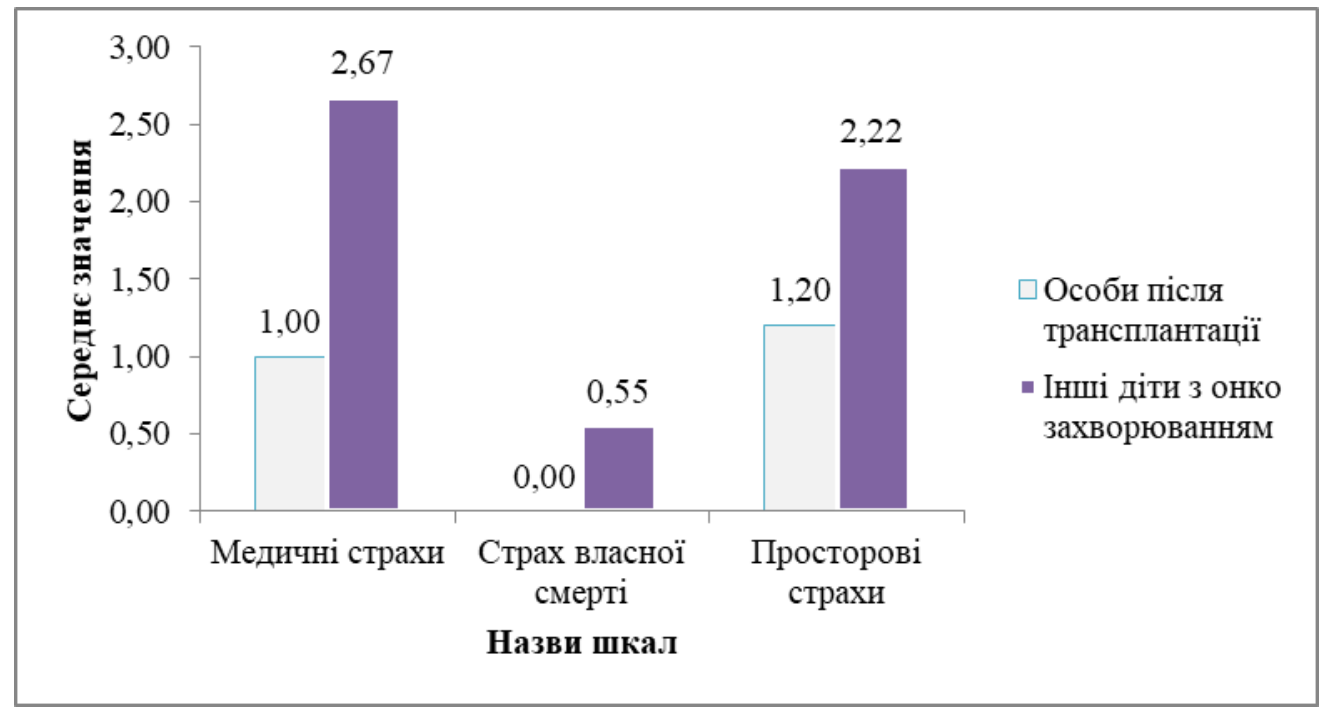

Рис. 9. Статистично значущі відмінності між досліджуваними дітьми з онкологічними захворюваннями, які пройшли трансплантацію, та іншими хворими досліджуваної групи за шкалами методики виявлення дитячих страхів A. I. Захарова, (t-тест Стьюдента)

Висновки й перспективи. Отже, за даними проведеного дослідження можна визначити, що діти з онкогематологічними захворюваннями та відносно здорові 3 контрольної групи характеризуються відмінними домінантними страхами. Також у ході дослідження виявлено, що діти, які первинно перебувають у лікарні, схильні більше переживати медичні страхи, страхи тварин, страхи казкових героїв, просторові страхи, страхи кошмарних снів, що може бути пов'язано 3 адаптацією дитини до лікарні, страхом перед болем, відчуттям загрози, шоковим станом батьків.

Опитані, які тривалий час перебувають на лікуванні, відзначалися найвищими рівнями схильності боятися страху смерті батьків. Цей 
страх може бути тісно пов'язаний зі страхом розлуки з батьками, страхом бути покинутим, страхом бути відторгненим власними батьками. Установлено, що діти, які перебувають у лікарні довгий час, готуються або пройшли ТКМ, мають термінальну стадію захворювання, характеризуються нижчим рівнем медичних страхів. У той самий час із проведеного дослідження виявлено, що опитувані, які переживають рецидив захворювання, та діти, котрі перебувають на термінальній стадії, характеризуються нижчим рівнем схильності боятися власної смерті. Можна припустити, що чим ближче дитина відчуває загрозу власному життю, тим більше спроможна витісняти страх смерті за допомогою психологічних механізмів захисту.

Опитані 3 досвідом реанімації та діти після проходження ТКМ характеризуються вищими рівнями страхів фізичних ушкоджень. Можна припустити, що дитина спроможна переживати інвазивні маніпуляції як певну загрозу. Також схильність боятися фізичних ушкоджень виявилась у дітей, які досягли ремісії, у цьому випадку це може вказувати на завуальований страх повернення хвороби, страх рецидиву.

Аналіз дослідження засвідчив, що діти, які досягли ремісії та перебувають на амбулаторному лікуванні, характеризуються вищим рівнем соціальних страхів. Така тенденція може свідчити про те, що діти, які досягли ремісії, перебувають поза межами стаціонару й готуються до повернення в соціальне життя, зустріч із соціальними викликами після тривалого лікування може спричиняти певні страхи. Iз проведеного нами дослідження можна зробити висновки, що домінантні страхи в дітей 3 онкологічними захворюваннями значно відрізняються на різних етапах лікування й тісно пов'язані 3 індивідуальним досвідом хвороби.

Перспективою подальших досліджень убачаємо в більш детальному вивченні екзистенційних страхів у дітей з онкологічними захворюваннями.

\section{Література}

1. Біннебезель, Й., Католик, Г. (2018). Паліативно-хоспісна опіка: позамедичні багатовимірні аспекти. Львів: Укр. кат. ун-т. NowaWies: Wydawnictwo Rolewski.

2. Бирюкова, И. А (2018). Психологические особенности детей, страдающих онкозаболеваниями. Известия высших учебных заведений. Уральский регион, 1, 107-112. 
3. Захаров, А. И. (2000). Дневные и ночные страхи у детей. Санкт-Петербург: Союз.

4. Исаев, Д. Н. (2004). Детская медицинская психология. Психологическая педиатрия. Санкт-Петербург: Речь.

5. Католик, Г. В., Стульківська, М. М. (2020). Сприйняття дітьми смерті: вікові та больові аспекти. Соціально-правові студіï, 2(8), 210-217. DOI: https://doi.org/10.32518/2617-4162-2020-2-210-217

6. Киян, И. Г. (2003) Личностные особенности детей, страдающих острым лимфобластным лейкоцитозом. Автореф. дис. канд. психолог. наук. Рос. гос. мед. ун-т.

7. Куртанова, Ю. Е., Бурдукова, Ю. А., Щербакова, А. М., Щукина, В. Д., Иванова, А. А. (2020). Социальная адаптация детей с онкологическими заболеваниями. Электронный журнал. Современная зарубежная психология, 9(3), 127138. DOI: https://doi.org/10.17759/jmfp. 2020090312

8. Скаковська, А. В. (2019). Вивчення невербальних страхів у дітей 3 онкогематологічними захворюваннями. Київський науково-педагогічний вісник. (18), 116-120.

9. Скаковська, А. В. (2020). Дослідження кореляційного зв'язку страхів та якостей особистості у дітей 3 онкологічними захворюваннями. Матеріали II науково-практичної конференції. «Гуманітарні та природничі науки: актуальні питання», 122-126. Дніпро.

10. Шац, И. К.(2016). Больной ребенок и его семья: формы и возможности психологической помощи. Санкт-Петербург: СпецЛит.

11. Binnebesel, J. (2000). Opieka nad dzieckiem z chorobą novotvorową. Aspekt pozamedyczny. Toruń: Wydawnictwo Naukowe Uniwersytetu Mikołaja Kopernika.

12. Góralczyk, E. (1996). Choroba dziecka w twoim życiu.Warszawa: Centrum.

13. Góralczyk, E. (2009). Dziecko przewlekłe chore. Psychologiczne aspekty funkcjonowania dziecka w szkole i przedszkole. Warszawa: Centrum Metodyczne Pomocy Psychologiczno-Pedagogicznej Ministerstwa Edukacji Narodowej.

14. Varni, J. W., Katz, E. R., Colegrove, R. Jr., Dolging, M., (1995). Perceived physical appearance and adjustmen with newly, diagnosed cancer; a path anlytic model, J. Behav. Med. (J58), Jun. 18 (3).

15. Ślepowrońska, D., (1989), Opotrzebie badania wiedzy potocznej dzieci dotyczą cejśmierci. Psychologia Wychowawcza, 2(3). Lwów; Warszawa.

\section{References}

1. Binnebezel, H. Katolyk. (Ed.). (2018). Paliatyvno-khospisna opika: pozamedychni bahatovymirni aspekty [Palliative-hospice care: extra-medical multidimensional aspects]. Lviv: Ukrainian Catholic University. NowaWies: Vydavnitstno Rolevski (in Ukrainian).

2. Birjukova, I. A. (2018) Psihologicheskie osobiennosti detej, stradajushchih onkozabolievanijami [Psyhologial features of children with cancer]. Izvestija vysshih 
uchebnyh zavedenij. Ural'skijregion - Proceedings of higher educational institutions. Ural region, 1, 107-112, Cheljabinsk: IzLiT (in Russian).

3. Zakharov, A. I. (2000). Dnevnye i nochnye strakhi u detei [Children's Daytime and Night Fears]. Sankt-Peterburg: Soiuz (in Russian).

4. Isaev, D. N. (2004). Detskaya meditsinskaya psikhologiya. Psikhologicheskay pediatriya [Children's medical psychology. Psychological pediatrics]. SanktPeterburg: Rech Publ (in Russian).

5. Katolyk, H. V., Stulkivska, M. M. (2020) Spryiniattia ditmy smerti: vikovi ta boliovi aspekty. [Children's perception of death: age and pain aspects]. Sotsialnopravovi studii - Socio-legal studies, 2(8), 210-217. DOI: https://doi.org/10.32518/ 2617-4162-2020-2-210-217 (in Ukrainian).

6. Kyjan, I. K. (2003) Lichnostnye osobennosti detej, stradaiushchih ostrym limfoblastnym leikotsytozom. [Personal characteristics of children with a cute lymphoblastic leukocytosis]. Extended abstract of candidate's thesis. Rossijskij gosudarstvennyj medicinskij universitet (in Russian).

7. Kurtanova, Yu. E., Burdukova, Yu. A., Shcherbakova, A. M., Shchuckina, V. D., \& Ivanova, A. A. (2020). Social'naja adaptacija detej s onkologicheskimi zabolevanijami [Social adaptation of children with cancer after prolonged treatment]. Elektronnyj zhurnal, Sovremennaja zarubezhnaja psihologija - Electronic journal, Contemporary foreign psychology, 9(3), 127-138. DOI: https://doi.org/10.17759/ jmfp.2020090312 (in Russian).

8. Skakovska, A. V. (2019) Vyvchennia neverbalnyh strahiv u ditei z onkohematolohichnymy zahvoriuvanniamy. [Study of nonverbal fears in children with oncohematological diseases]. Kyivskyi naukovo-pedahohichnyi visnyk - Kyiv Scientific and pedagogical bulletin, 18, 116-120 (in Ukrainian).

9. Skakovska, A. V. (2020). Doslidzhennia koreliatsiinoho zviazku strahiv ta yakostei osobystosti $\mathrm{u}$ ditei $\mathrm{z}$ onkolohichnymy zahvoriuvanniamy. [A study of the correlation between fears and personality traits in children with cancer]. Materialy II naukovo-praktychnoi konferentsii «Humanitarni ta pryrodnychi nauky: aktualni pytannia», 122-126. Dnipro (in Ukrainian).

10. Shats, I. K. (2016). Bolnoi rebenok i ego semya: formy i vozmozhnosti psikhologicheskoi pomoshchi [A sick child and his family: the forms and possibilities of psychological help]. St. Petersburg: SpetsLit Publ. (in Russian).

11. Binnebesel, J. (2000). Opieka nad dzhetskem $z$ khorobou novotvorovoun. Aspekt pozamedychny [Caring for a child with cancer. Non-medical aspect]. Torun': Vydavnitstvo naukove universytetu Mikolaya Kopernika (in Polish).

12. Guralchyk, E. (1996). Khoroba dzhetska v tvoim zhychu. [Child's disease in your life.]. Warshava: Tsentrum Metodychne Pomotsy Psyhologichno- Pedagogichnei Ministerstva Edukatsii Narodovei (in Polish).

13. Guralchyk, E. (2009). Dzhetsko pshevlekve khore. Psyhologichne aspekty funktsionovania dzhetska v shkolie i pshedshkolie [Chronic sick child. Psychological aspects of a child's functioning at school and kindergarten]. Warshava: Tsentrum Metodychne Pomotsy Psyhologichno-Pedagogichnei v Warshavie (in Polish). 
14. Varni, J. W., Katz, E. R., Colegrove, R. Jr., Dolging, M. (1995). Perceived physical appearance and adjustmen with newly, diagnosed cancer; a path anlytic model, J. Behav. Med. (J58), Jun. 18 (3).

15. Shlepovronska, D., (1989). Opotszhebe badania vedzy potochnei dzheti dotychontsei shmerti [About the need to study the common knowledge of children about death]. Psyhologiia Vyhovavcha - Psychology of Education, 2(3), Lvuv; Warshawa (in Polish).

Received: 26.10 .2020

Accepted: 28.11.2020 